\title{
The Insanity Defence: How Do We Handle Doubt?
}

\author{
RANDI ROSENQVIST ${ }^{\star}$
}

\section{Introduction-The Medical principle}

According to Norwegian legal tradition, criminal legislation has since the $13^{\text {th }}$ century practiced a distinctive penal provision for criminals who suffer from insanity. ${ }^{1}$ Our current legislation has yet gone through great changes since the Criminal Code was passed in $1842 .{ }^{2}$ The criminal legislation was altered in $1848,1902,{ }^{3} 1929,1997$, and in the current 2005 Penal Code, ${ }^{4}$ which has been amended by a new bill this year. ${ }^{5}$ The overriding principle is that some offenders must be acquitted due to reasons of insanity. Criminal insanity is understood legally as a range of medical condi-

* Psychiatrist; Consultant at Oslo University Hospital, Center for Forensic Psychiatry and Ila Prison and Preventive Detention Centre.

As a forensic psychiatrist, I have worked with insane and sane criminals through my whole career. I have also participated in the development of new legal standards for insanity in the Norwegian penal code. It is my experience that the politicians, the forensic experts and the courts all have difficulties in understanding the best way to handle uncertainties in whether a charged person is legally sane or insane. I am, therefore, grateful for the opportunity to write this paper. I also thank law student Frida Finstad Gilje of Bergen University for helping me so that this paper hopefully meets the standards for a legal paper, although a psychiatrist has written it.

1 Hagland and Sandnes, Frostatingslova (Samlaget and Frosta Historielag, Oslo 1994), p 67, insanity is here described in Norwegian as 'Om ein mann vert så galen at han bryt seg or banda [...]' (If a man is so mad that he breaks out of constraints).

2 LOV-1842-08-20-12 om Forbrydelser, 'Kriminalloven' (the Criminal Code).

3 LOV-1902-05-22-10 Almindelig borgerlig Straffelov (the General Civil Penal Code), section 44.

4 LOV-2005-05-20-28 om straff (the Penal Code), section 20.

5 Prop. 154 L (2016-2017); Innst. 296 L (2018-2019). The proposed bill has been passed by Parliament, and the amendment to the Penal Code section 20 was sanctioned by the King in the Council of State on 21 June 2019, but is not yet in effect. 
tions that are defined in criminal legislation and preparatory papers-these sources of law stress that this includes only very ill persons. The fact that the defendant was criminally insane at the time of the crime is the reason for acquittal, ${ }^{6}$ and there is no need to prove that the crime was a result of the condition. This constitutes the 'medical principle' according to Norwegian legal tradition. The medical principle is unlike the 'psychological principle' that most countries apply, which requires a causal connection between the medical condition and the crime.

This paper presents the difficulties in constructing a legal rule regarding the insanity defence that is understood by courts, attorneys, psychiatrists and psychologists. These disciplines are very different in theory and in practice. One of the biggest challenges regarding the legal regulation of insanity is that legal thinking must conform to psychiatry. In this paper, I present how the Norwegian Penal Code uses the term 'psychotic' as the specification of those who are to be acquitted. ${ }^{7}$ I will also elaborate on the difficulties that appear when the forensic experts are uncertain in their diagnostic assessments, and discuss how the new bill ${ }^{8}$ might alter forensic psychiatry and current legislation. I am very unhappy about the possible consequences of this bill-I find the legal and the psychiatric terms to be poorly defined, and in my opinion the amendment will not lead to equality before the law.

I believe that a hundred years ago most people accepted the principle that insane criminals were to be acquitted. They were then normally civilly committed to psychiatric hospitals according to the Mental Health Law. ${ }^{9}$ Many were to spend the rest of their lives in hospitals, as this was considered a sufficient penalty. Today, psychiatric treatment is so advanced that very few patients spend a long time in hospitals. Those who are considered to pose a potential risk of new violent behaviour can be sentenced to psychiatric treatment. ${ }^{10}$ A very ill schizophrenic person who has committed murder might be able to safely live in his own home just a few years later. This may lead some people to the opinion that some insane criminals should instead be sentenced to prison and serve a full sentence.

The Norwegian Parliament has passed a new bill that opposes the medical principle. ${ }^{11}$ The bill states that the very ill shall be acquitted but emphasises that the court must find it 'reasonable and just' to acquit. ${ }^{12}$ I believe that this is unwise. It is difficult for courts and for the public to understand how ill a very psychotic person is. The answer to the philosophical question of what is reasonable and just is not obvious.

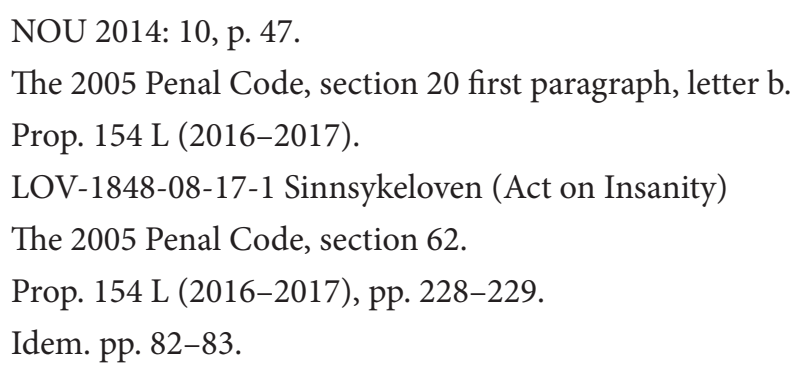




\section{Background}

The Norwegian legislation has used the term 'insane' since $1848 . .^{13}$ The term included those who should be acquitted in a criminal case as well as those who were so mentally disturbed they could be admitted involuntarily to the mental hospitals. ${ }^{14}$ Both doctors and lay people used the term alike. We know that insane patients suffered from what we now call schizophrenia, affective psychosis, paranoid psychosis, organic psychosis, dementia, syphilis, serious autism, mental retardation, and other forms of brain damage. ${ }^{15}$ The psychiatric diagnoses have become more and more sophisticated over the years since. The diagnostic system that is used in psychiatry in Norway today was introduced in $1999^{16}$, and soon there will be a new diagnostic manual. ${ }^{17}$

During the last century, the Penal Code defined 'insane' as people who were criminally incapable of being held responsible. The term comprised offenders who suffered from the conditions mentioned above, and these persons were acquitted when their symptoms were considered sufficiently severe. Most of the people who were considered insane were transferred to long-term confinements in mental hospitals. After the revision of the Penal Code in 1929, the court could sentence an acquitted offender to security measures in a mental institution. Previously, the patient would have been admitted through the civil insanity law.

Another group considered criminally incapable were those who were described as 'unconscious' at the time of the crime. ${ }^{18}$ This included people who suffered from epilepsy, contusion, some intoxications, heavy fever, and in some cases, hysteria. 'Automatism' is the English term that is typically used when referring to these cases. These specific conditions incapacitate the person only for a short period of time. They would be acquitted mostly without any security measures; however, patients suffering from epilepsy with recurrent attacks could be placed in a suitable institution for their own safety and for the safety of others.

It is well established that the treatment of mental illness has improved dramatically since 1950, and especially after the development of the first effective medicines against

13 The term 'sinnssyk' (insane) was implemented into the 1842 Criminal Code in 1848 so as to correspond with the 1848 Act on Insanity.

14 See the 1848 Act on Insanity.

15 Langfeldt, Rettspsykiatri (Aschehoug 1947), chapter 3.

16 World Health Organization, The ICD-10 Classification of Mental and Behavioural Disorders, Diagnostic criteria for research (Geneva, WHO, 1992). Norwegian publication: ICD-10 psykiske lidelser og atferdsforstyrrelser kliniske beskrivelser og diagnostiske retningslinjer (Gyldendal Norsk Forlag 1999).

17 ICD-11 might become the official diagnostic manual in Norway in a few years. This manual will have other definitions of mental illnesses than the one currently in use.

18 Langfeldt, Rettspsykiatri chapter 3. See also Langfeldt, Eitinger and Retterstøl, Rettspsykiatri, 3rd ed. (Universitetsforlaget 1984) and Rosenqvist and Rasmussen, Rettspsykiatri i praksis (Universitetsforlaget 2001). 
psychosis. Due to the effectiveness of new medications, as well as the social security net provided by the disablement pension, patients were frequently released from hospitals. In addition, there was a growing focus on the right to personal autonomy. The political aim was for all psychiatric patients to live in their own homes and only be admitted to hospitals for short periods when they were gravely ill. In 1960 there were about 18,000 beds in Norwegian mental institutions, whereas there were 3,444 beds in 2017. ${ }^{19}$

The Mental Health Act of 1848 was revised in $1961 .^{20}$ The term 'insanity' was removed and the term 'severe mental illness' ${ }^{\text {'1 }}$ was introduced as a new criterion for involuntarily commitment. Before the law was passed, there was discussion as to whether the term ought to be 'psychotic'. This is a more clinical expression, but it was argued that the term 'psychotic' would be a too exclusive term. In the criminal legislation, however, the term 'insanity' remained until 2002. When the current mental health law was passed, the term 'severe mental illness' was sustained. ${ }^{22}$ It is a legal term and it does not completely correspond with any psychiatric diagnoses.

\section{Current Legislation}

The new insanity concepts of the Penal Code of 1902 entered into force in 2002. In regards of the preparation in 1990 it was proposed to exchange the term 'insane' with the following terms: ${ }^{23}$

1. 'Psychotic, and therefore lacking the ability to realistic assessment of the outside world'. ${ }^{24}$

The intention was also to define the mentally retarded as a unique group:

2. 'Severely mentally retarded', 25

and keep the old formulation:

3. 'Unconscious', ${ }^{26}$ which in many cases corresponds with the term 'automatism' in other legislations.

19 Data from Statistisk sentralbyrå (Statistics Norway), found at: https://www.ssb.no/statbank/ table/04511/ (All weblinks last accessed $9^{\text {th }}$ September 2019).

20 LOV-1961-04-28-2 om psykisk helsevern (Act on Mental Health Care).

$21 \quad$ Ibid, section 5

22 LOV-1999-07-02-62 om etablering og gjennomføring av psykisk helsevern (Act on Mental Health Care), section 3-3 number 3 and section 4-4a number 2.

NOU 1990: 5, pp. 9-10

Implemented into section 44 of the 1902 Penal Code.

Implemented into section 45 first paragraph of the 1902 Penal Code.

Implemented into section 45 second paragraph of the 1902 Penal Code. 
The preparatory papers stated that, in contrast to earlier times, psychosis did not necessarily mean a chronic, possibly lifelong condition. ${ }^{27} \mathrm{~A}$ person could, for example, have the main diagnosis F 20.0 Paranoid schizophrenia but still function quite well and should therefore be considered legally culpable. The preparatory papers argued that the severity of illness was the relevant factor in justifying the acquittal, that the perpetrator must have suffered from a psychosis and therefore lacking the ability to realistic assessment of the outside world. The new legal terminology was formulated to identify those who were so ill that they previously would have been considered 'insane'. It was intended to exclude those who might, for example, have a diagnosis of schizophrenia with few symptoms and could lead a nearly normal life.

In the processing of the bill in the Ministry of Law, ${ }^{28}$ this description of the relevant characteristic of psychosis was removed from the legal rule because it was considered unnecessarily precise. The ministry wrote (my translation):

It is to be expected that those who primarily will practice the legal rule are primarily people of the legal profession with help from psychiatrists. They will have an intimate knowledge of what characterises a psychosis, and for them such precision will be unnecessary.29

As I interpret this, the Ministry meant that only those who were so ill as assumed in the preparatory papers should be acquitted, but it was not necessary to state this in the legislation. This was, in my opinion, a very unwise decision.

A person can be affected by a hallucinatory voice, which is a psychosis symptom. Yet such a hallucinatory voice does not necessarily mean it will greatly impact the persons reasoning. Unlike a hundred years ago, psychosis is today considered more of a dimension than a category. By removing the essential dimensional clarification from the preparatory papers, the Ministry invited the misinterpretation that any psychosis will result in acquittal. This is a notion people have difficulty accepting. The mental health organisations protest against the notion that having a diagnosis such as schizophrenia means that you cannot be held responsible for your actions. Others will have the wrong impression that if you have such a diagnosis you can commit shoplifting without any consequence. Representatives of the legal profession and journalists have often claimed in public that it is the diagnosis that automatically renders an acquittal. ${ }^{30}$ This is not the case, and it is rather the seriousness of the condition at the time of the crime that is decisive.

Although I do not have any empirical evidence, I would from my experience esti-

$27 \quad$ NOU 1990: 5, pp. 38-39.

$28 \quad$ Ot.prp. nr. 87 (1993-94) pp. 28.

29 Ibid. Original text: 'Det må kunne forventes at de personer som først og fremst skal praktisere bestemmelsen, det vil si jurister med hjelp av psykiatere, er klar over hva som kjennetegner en psykotisk tilstand. For dem er presiseringen unødvendig.'

30 See, for example, Gran, Hundreår med hodebry - utilregnelighetens historie (Cappelen Damm 2014). 
mate that the vast majority of those who currently have the main diagnosis of schizophrenia (between $0.3 \%$ and $2 \%$ of the Norwegian population ${ }^{31}$ ) would be considered legally sane and culpable today. They live their lives in the community and function quite well. Most schizophrenic patients do not commit crimes, and those we read about in the papers having committed serious crimes are usually very ill. There are approximately 100 cases a year where the forensic experts conclude that an offender is 'psychotic' in the legal sense. ${ }^{32}$ Most of these offenders suffer from schizophrenia, the remainder from other illnesses in the psychosis spectrum.

A completely revised Penal Code was passed in 2005. But the definition of legal insanity ${ }^{33}$ follows the previous legislation and preparatory papers. Section 20 now reads:

'To be liable for punishment the offender must be accountable at the time of the act. The offender is not accountable if, at the time of the act, he/she is
a) under 15 years old,
b) psychotic,
c) severely mentally disabled, or
d) suffers from a severe impairment of consciousness.

Impairment of consciousness as a result of self-induced intoxication provides no exemption from punishment.'

The criteria b), c), and d) are legal terms, although one might think they are psychiatric diagnostics. In my opinion, it is essential that these legal terms are well defined and understood. In my experience, that is not always the case, although the preparatory papers describing these legal terms are plentiful. ${ }^{34}$

After the terror attack in Norway in 2012, ${ }^{35}$ a legal board was appointed by the government to revise the insanity legislation. They proposed a bill in 2014, ${ }^{36}$ which was processed in the Ministry of $\mathrm{Law}^{37}$ and has now been passed by Parliament. ${ }^{38}$

31 Data from Norsk Helseinformatikk (Norwegian Health Informatics), found at: https://nhi.no/ sykdommer/psykisk-helse/schizofreni/schizofreni-forekomst/

32 Den rettsmedisinske kommisjons årsmeldinger (annual reports of the National Forensic Medical Board). Today one cannot find these figures in the annual reports, but from 1990 to 2010 the number of such cases was quite stable. Reports from 2002-2018 are available (in Norwegian) at: https://www.sivilrett.no/arsmeldinger.339263.no.html

33 The 2005 Penal Code section 20 second paragraph.

34 NOU 1974: 17; NOU 1983: 57; NOU 1990: 5; NOU 2002: 4.

35 RG-2012-1153.

36 NOU 2014: 10. For a further explanation of this proposal, see Gröning and Rieber-Mohn, 'NOU 2014:10 - Proposal for New Rules Regarding Criminal Insanity and Related Issues, Norway post 22-July', Bergen Journal of Criminal Law and Criminal Justice 3(1) (2015) pp. 109-131.

37 Prop. 154 L (2016-2017).

38 See footnote 5 . 


\section{The Current Psychiatric Diagnostic Manual: Impact of the ICD-10}

This chapter primarily discusses the modern definition of 'psychotic'. I also discuss other groups associated with criminal incapacity to demonstrate that neither 'severe mental retardation' nor 'unconsciousness' is identical with any psychiatric diagnosis.

The psychiatric profession went through a new phase when the international diagnostic manual ICD-10 $0^{39}$ became the official diagnostic system in Norwegian psychiatry in 1999. With an official definition of different mental illnesses, the diagnostic procedure became more exact, but also more complex. One example is that the diagnosis of schizophrenia is divided into several subgroups. These subgroups aim to describe the state of the illness at the time the diagnosis was set. A very ill patient might have the diagnosis F 20.00 Paranoid schizophrenia, continuous, but later F 20.04 Paranoid schizophrenia, incomplete remission, and yet later F 20.05 Paranoid schizophrenia complete remission. As one can see, the main diagnosis is stable, but the symptoms are not. A person would probably only be acquitted for crimes committed during the periods when his or her illness was considered severe at the time of the crime, as in F 20.00.

Another example is the diagnosis F 84.0 Childhood autism. This diagnosis is no longer considered a psychosis in the ICD-10. This is regarded as a pervasive developmental disorder, despite the fact that such a patient might have a complete lack of understanding of reality. He or she would earlier be considered 'insane' and would typically be considered as having a 'severe mental illness' if admitted to a psychiatric facility. In contrast, today the patient would primarily receive the same type of care as those considered mentally retarded. This has important consequences for the understanding of the insanity defence. Nevertheless, it seems to me that the somewhat conservative way of legal thinking has not taken this new systemisation of diagnoses into consideration. The legal concept of insanity has not changed, but the psychiatric diagnoses have.

According to forensic psychiatric tradition, the psychiatric experts conclude that the offender meets the criteria of insanity, and psychosis in the legal sense, only when they are clinically sure of this. ${ }^{40}$ The experts should assume the offender was culpable until they have sufficient clinical information to say he was not. Doubts should be described so that the court can take these into consideration when rendering a verdict.

The preparatory papers discuss the procedure in the cases where the experts could not conclude that the offender was psychotic in the legal sense. It might be the case the offender had a severe mental illness at the time of the crime, but the experts could not say how severe his condition was at the time of the crime. It was proposed that the experts could then conclude (my translation): '[the offender] had a serious

\footnotetext{
39 See footnote 16.

$40 \quad$ Langfeldt (1947), see also Rosenqvist og Rasmussen (2001), p. 63.
} 
mental illness with a considerable reduction of the ability to realistic assessment of the outside world, but was not psychotic" ${ }^{11}$ The proposal was that these cases should not automatically render a verdict of criminal responsibility, but that the court could use their discretion and acquit the person charged if deemed 'reasonable and expedient." ${ }^{42}$

This was meant to apply to cases of schizophrenia, affective disorder, or other psychosis illnesses with symptoms that were not sufficiently intense. In the preparatory papers it was also stated that a person with an autistic disorder might or might not be found criminally non-responsible, even though an autistic disorder is not in the ICD-10 considered a psychosis. The experts could then describe the state of the impaired offender without concluding that he or she was clearly psychotic in the legal sense. The courts would then be responsible for deciding whether the charged person, who certainly would not be mentally healthy, should be acquitted or not.

This proposed section of the Penal Code was not accepted by the Parliament when the bill was passed in $1997 .{ }^{43}$ The Penal Code now states that the accused is either clearly psychotic in the legal sense and must be acquitted, or does not fill the legal criteria for psychosis and must be found criminally responsible. There is no legal category where the court can use their discretion. But, as I will discuss later, when the court is in doubt, the court must consider how this doubt must be handled. One must not forget that it always is the court and not the forensic expert that decides whether the charged should be found criminally responsible or not.

The diagnostic manual ICD-10 also has a chapter on mental retardation. Mild mental retardation is basically defined as having an IQ under 70 and over 49 . Moderate mental retardation is defined as an IQ in the range 35 to 49 . In the legal sense, however, the categorisation of the severity of mental illness is defined somewhat differently. ${ }^{44}$

Those who were to be legally considered 'severely mentally retarded' were defined as those who had an IQ lower than 55, as was the practice with the old term 'insane'. According to ICD-10 F 70, mild mental retardation is defined as those with an IQ in the range of 50 to 69 . Therefore, persons legally defined as severely retarded can clinically be described as mildly retarded. Those who in the legal category of 'mild mental retardation' were defined with an IQ between 55 and 75. This does not correspond with the diagnostic manual.

It is problematic that the legal terms do not coincide with a clear psychiatric diag-

$41 \quad$ NOU 1990: 5, p. 38. Original text: '[l]ovbryterens manglende evne til realistisk vurdering av sitt forhold til omverdenen må vore relativ generell, dvs at mangelen må omfatte vesentlige sider av virkeligheten, for at lovbryteren skal erkloeres psykotisk'.

$42 \quad$ NOU 1990: 5, p. 49 and p. 61 'akultativ straffrihet'.

43 Innst.O.nr.34 (1996-97) Innstilling fra justiskomiteen om lov om endringer i straffeloven mv. (Recommendations from the Standing Committee on Justice regarding amendments to the Penal Code).

$44 \quad$ NOU 1990: 5, p.52. 
noses, but as long as one remembers that the terms 'psychotic' and 'severely mentally retarded' as used in section 20 of the Penal Code are legal concepts and not clinical diagnoses, these terms are reasonably well defined in the legal literature.

The term 'severe impairment of consciousness' is rarely applied. This might be because people suffering from epilepsy, diabetes, and other illnesses that can result in lack of consciousness receive much better treatment today than a hundred years ago. The state of 'a severe impairment of consciousness' can also be a state of intoxication, either from alcohol or other harmful substances; however, there is a statute that states that unconsciousness due to self-inflicted intoxication does not nullify criminal responsibility. ${ }^{45}$

\section{How Do Experts Assess and How Do They, and the Courts, Handle their Conclusion and Uncertainties}

In forensic psychiatric practice today, the experts have the mandate to state whether they find the accused was 'psychotic' at the time of the crime. Before doing this, they must have assessed the accused person thoroughly. Information from previous care in the mental health system and primary health care must be assembled with the permission of the offender. He or she must undergo interviews with two independent and impartial experts who have also received all documents from the police. The majority of such assessments are conducted in prison, in the charged person's home or in the expert's office. The accused can also be admitted to a psychiatric hospital when the experts find this necessary to conclude on the issue of psychosis. ${ }^{46}$

When the experts write their report, they must first describe the person they assess. All relevant information must be presented. The experts are not to have any opinion as to whether the charged has committed the offence or not. They shall not perform a judgment of other evidence in the case that is irrelevant to the psychiatric assessment. The experts are responsible for the purely medical matter of discussing and setting the psychiatric diagnosis. I will present an example with the diagnosis paranoid schizophrenia (F 20.0) to illustrate my point. The expert must discuss how impaired the accused is assumed to have been at the time of the crime and subsequently consider whether his or her condition meet the criteria of 'psychotic' in the legal sense. ${ }^{47}$ It is not easy specify how ill a person was at the time of the crime, as this might be a while ago. The experts have to consider all relevant information and make an assessment.

I will now present four different cases I have known either as an expert, as Head

\footnotetext{
45 The 2005 Penal Code section 20 (2).

46 LOV-1981-05-22-25 om rettergangsmåten i straffesaker (Criminal Proceedings Act) section 167.

47 The 2005 Penal Code section 20 first paragraph, letter b.
} 


\begin{abstract}
of the Norwegian Forensic Medical Board, or as a psychiatrist working in prison. I have rewritten these cases to present typical cases and difficult cases, and to secure anonymity.
\end{abstract}

\title{
Case 1:
}

A man of about 50 years of age has had the diagnosis of schizophrenia for about 30 years. He lives mostly on the street. He receives antipsychotic drugs via an injection every two weeks and fares tolerably. He steals money, mobile phones and alcohol that he sells to fend for himself. He explains that he knows it is wrong to steal, but he needs the money. He also claims that the police cannot arrest him since he suffers from schizophrenia. Nevertheless, he knows that he needs to change his habits if the law changes. The experts find no evidence of on-going delusions or other positive psychotic symptoms.

The forensic experts conclude that he suffers from schizophrenia, but in incomplete remission (F 20.04). In their opinion, his symptoms are not severe enough to meet the criteria of 'psychotic' in the legal sense. He is sentenced to prison.

\section{Case 2:}

A 35-year-old man has had the diagnosis of schizophrenia for about six years. He committed a crime by killing his own uncle. He spent several months in hospital one year previous to the crime. He was hospitalized because of his severe symptoms, he had great fear of someone- 'they' will send him to the Amazon as an object for scientific experiments. After heavy medication, he improved sufficiently to move into his own house. His house was a ten-minute walk from his uncle's flat. He moved during June and took his medication. Things went fine for some months, but by October he seemed more verbally aggressive toward his uncle and would not let him into his flat. His uncle was afraid that he had stopped taking his medication. In December, he threw objects out of the window and locked the door. The uncle did not want to call the police because his nephew did not like him interfering. A few days later, he came to his uncle's house and killed him with his own axe. He was arrested and was not willing to talk to the police. He was admitted to hospital, where he seemed very frightened and declined to talk. He received medication and, after some time, he started to talk. He said that everything would be all right; his uncle had been hospitalised abroad for some time, but he would be back for his trial.

The experts conclude that he has schizophrenia, and the situation at the time of the crime is so deteriorated (F 20.00) that they consider him 'psychotic' in the legal sense. In accordance with the 'medical principle', the experts do not discuss whether the illness was the reason for the murder.

These two examples are quite uncomplicated from a psychiatric point of view. The courts will assess the cases, but it is highly unlikely that they will disagree with the experts. $^{48}$

The forensic report is also sent to the Norwegian Forensic Medical Board, a 
peer-review board appointed by The Ministry of Law. ${ }^{49}$ The board will give the court notice if they find the report incomplete. They will make comments if they find that the accused has not been sufficiently examined or if they find that the psychiatric diagnoses have not been satisfactorily set. Consequently, the board will respond if they find that the expert performing the assessment has an understanding of the legal term 'psychotic' which they cannot accept. In this way, the Forensic Board seeks to set a standard for the legal terms.

Until 2018, the jury in the Court of Appeals gave acquittal without an explanation. According to Norwegian legislation, the Supreme Court cannot alter their ruling. Therefore, there is little judicial authority on how the insanity defence should be practised. We only have the preparatory papers ${ }^{50}$ and other legal literature. ${ }^{51}$ The former jury system has now been replaced by a court with professional judges and lay assessors. They will have to justify their rulings, which should provide a better guarantee for due process of the law.

As stated above, the experts will only conclude 'psychotic' when they are clinically certain in their case. The assumption is that the court mostly follows the experts in obvious cases. However, a problem arises in regard to the courts' assessment of the uncertain cases. This uncertainty can, for example, be caused by the psychiatric diagnosis, or due to the estimation of the strength of the symptoms at the time of the crime.

A Supreme Court ruling covering this question (my translation) ${ }^{52}$ is confirmed in later rulings: ${ }^{53}$

'Even though the conclusion shows that the experts have not regarded the accused as insane at the time of the crime, the accused must be acquitted if the court-on the bases of the premises in the forensic report or of other reasons-finds it dubious that the accused was sane at the time of the crime.'

So, the prosecution has to prove sanity to get a conviction in cases where the accused might have been insane or 'psychotic'.

It is my impression that this is not the ruling in all cases. In one case I came to know, the offender was considered 'not psychotic' by the experts, and criminally responsible by the court, although there were many indications of insanity.

49 Den rettsmedisinske kommisjon, http://www.sivilrett.no/den-rettsmedisinske-kommisjon

50 NOU 1990: 5.

$51 \quad$ Andenæs, Alminnelig strafferett - 6th ed. by Rieber-Mohn and Sæther (Universitetsforlaget 2016); Gröning, Husabø, and Jacobsen, Frihet forbrytelse og straff. En systematisk fremstilling av norsk strafferett (Fagbokforlaget 2016).

52 Rt-1979-143 on page 147. Original text: 'Og selv om konklusjonen viser at de sakkyndige ikke har ansett tiltalte som sinnssyk på gjerningstiden, må tiltalte likevel frifinnes for straff dersom retten-på grunn av premissene i den rettspsykiatriske erkloering eller av andre grunner-finner det tvilsomt om tiltalte var tilregnelig da den straffbare handling ble begått'. 


\section{Case 3:}

A 23-year-old woman isolated herself in her room at her parent's house after leaving school at 19. Her childhood and youth were troublesome and other girls bullied her. She had no boyfriends. When her father died in a car-accident she had to move and, on that occasion, she tried to kill her brother and mother and set fire to the house by lighting a candle and spreading gasoline in her room. As she tried to stab her family, she told them that they had ruined her hair while cutting it for her when she was younger, and she had planned this assault for more than ten years. The police were soon there and informed her that she had the right not to explain herself. After that, she did not speak to anybody for about two years. However, she did answer questions by typing short sentences on the computer. The police found 20 large knives and gasoline in her belongings. She did not belong to a criminal gang. The experts asked her about her collection, and she wrote that he had an interest in knives. She also repeated that she had committed the assault because of the insults she had been subjected to. She strongly denied psychotic symptoms. However, she had had shown peculiar behaviour, behaviour which is often described as 'negative symptoms' in schizophrenia, including perseveration (difficulties in ending an activity), such as brushing and combing her hair for several hours, and possibly a lack of spatial organisation (difficulties in understanding the spatial environment), as she always held her hand to the wall when she was moving in a room.

The experts cannot find certain evidence for her suffering from schizophrenia and settled for the diagnosis F 43.1 Post Traumatic Stress Disorders (PTSD) because of her difficult childhood. Since a psychotic illness was not identified, it was not relevant to discuss the term 'psychotic'. ${ }^{54}$ She is also regarded as homicidal and suicidal by a psychiatric consultant during a short stay in psychiatric hospital. She is convicted as sane.

In my opinion, in a case like this, the individual history gives a strong suspicion of schizophrenia, and the kind of silence exhibited by the offender is very uncommon. Her communication with others is very restricted. Although she may answer grammatically correctly, her reasoning is peculiar. It is not normal to plan to murder family members because of a hair-cut that went wrong eleven years earlier. 'Having an interest in knives', in this case knives suitable for stabbing, is unusual in a young woman and can also be interpreted as a defence against fear for one's own life.

A psychiatrist should not take everything the charged person says at face value. It is not reassuring if the forensic experts expect the accused to tell them openly of psychotic symptoms before they can set the diagnosis of schizophrenia. The experts should, in my opinion, analyse all peculiarities of the accused, not just look for obvious information about hallucinations and persecutions. It may for instance be that the young woman does not show symptoms that are common in persons with PTSD, but instead fits several criteria of a schizophrenic development. Many ill psychotic patients have great difficulties in telling doctors about their symptoms.

In my opinion, the next example serves as a good illustration of how experts have made inappropriate assessments of evidence that should have been left to the court. 


\section{Case 4:}

A person in his late forties kills his father. The offender has suffered from the diagnosis F25.2 Schizoaffective disorder, mixed type, for a very long time. He has been admitted to psychiatric hospital very many times, mostly because of short periods of paranoid delusions, due to religious speculation. He has also other disturbing ideas such as that certain birds are controlling him. He also suffers from short periods of depression. He sometimes contacts the hospital on his own but other times he is admitted involuntarily.

In the early stage of his illness, he claimed that he wanted to go to join the war in Iraq, although he has no connection to the area. Lately he has been more interested in observing birds and discussing religious matters.

The police interview him shortly after his father's death. He claims that he is psychotic, but he wants to go to prison and not to a forensic hospital. Some days later, he confesses to killing his father so that his mother would be able to cut down the apple trees in their garden. The forensic experts state that he suffers from a schizoaffective disorder but do not conclude that he was psychotic at the time of the crime. The experts consider that the man gave a conceivable motivation for the murder. This is justified by the fact that the crime was planned through the whole night and not carried out in an impulsive or chaotic way.

A month later the accused tells his consultant that he had developed a notion on the evening of the murder, that his father was the real Pope, the defender of birds, and it was his destiny to rid the world of him. The forensic experts are informed about this statement but do not alter the forensic report. They stress that it is his first confession that counts and that the latter is a construction in order to be acquitted. The jury finds him guilty.

This case shows how the experts can be not very fluent in diagnostic understanding. This offender has a serious psychotic illness with varying dramatic symptoms. They obviously consider their opinion of the man's motivation as important for their conclusion, although it is not their mandate to consider a motivation. I would add that it does not seem very reasonable to me to murder your father to give your mother the opportunity to cut down some apple trees in the garden. I was very surprised when, in the real case that my reconstruction is based upon, the Court of Appeal sentenced the offender as sane. I also wonder how the prosecutor and defence lawyer could in that case ignore, as stated above, the provision that: 'the accused must be acquitted if the court-on the bases of the premises in the forensic report or of other reasons-finds it dubious that the accused was sane at the time of the crime.'

From my perspective, the two last cases show that the court has difficulties in re-examining the forensic reports. The experts do not always clearly explain the uncertainties of their conclusions. The experts in case 4, the prosecutor, and the defence lawyer should have pointed out that the story about the real Pope was possibly a genuine paranoid delusion given the history of the illness. This might be difficult for the lay people of the jury and for some in the legal profession to understand if they have not met a very psychotic person. 


\section{Further Discussions and Hopes for the Future}

I am sure that the offenders in both case 3 and case 4 described above would have been found 'insane' if they had occurred twenty or thirty years ago. The term 'insane ${ }^{35}$ was not identical with psychiatric diagnoses. Does this mean that the state of the law was altered when the penal codes changed from using the term 'insane' to 'psychotic', or are these cases miscarriages of justice?

It was certainly not the intent to alter the definition of who should be found criminally insane in the law taken in effect in 2002, but by changing the terms one also changes the associations and impressions. It can be argued that using the term 'psychotic' has, to a high degree, connected the legal term to the clinical diagnoses. All the same, the law does not make sufficiently clear that it is the condition when the crime was committed and not the formal diagnosis that results in acquittal. As a consequence, the discussions in forensic reports often go in depth into criteria in the ICD-10 Manual, but they do not give a complete description of the function of the accused. This is something we see in clinical psychiatry as well. It seems that the use of checklists and other diagnostic procedures has replaced much of the clinical work in a psychiatric ward. As patients often spend only a few days in the hospital before they are discharged, there will be insufficient knowledge about their symptoms and their lives.

Another explanation of the difficulties in finding a very ill person 'psychotic', from a legal perspective, is that the psychotic state does not necessarily last very long if the person receives adequate treatment. People, including lawyers, politicians and psychiatrists, are often of the opinion that mentally ill people get away too easy when acquitted. They point to the fact that charged might not be in a psychotic state when the case comes to court. In my opinion, they have then not understood the nature of psychosis, nor understood that according to Norwegian law, the relevant question for acquittal is whether the offender was too ill to be criminally responsible at the time of the crime. The law also states that if the criminal is under the age of 15 when committing a crime, he will be acquitted. One does not wait until his birthday and then sentence him.

I believe that forensic psychiatrists and psychologists could improve their competence in diagnosing the severely ill. One needs to know a considerable amount about a person who might suffer from schizophrenia before one concludes that this is not the case. When a suspect tells different stories about his or her motivations, one should not automatically assume that the more 'normal' explanation is truthful, and the 'abnormal' is malingering. It is clinical experience that many psychiatric patients try to simulate 'normal' and conceal their symptoms. It is also a misinterpretation that a 'psychotic' person cannot commit a premeditated crime, although most of the violent crimes committed by 'psychotic' persons seem impulsive and unpredictable.

$55 \quad$ Norwegian: 'sinnssyk'. 
The Norwegian Medical Forensic Board should also be more critical to reports when uncertainty is not sufficiently disclosed. The prosecutors and defence lawyers must also try to understand psychiatric illnesses and not accept all forensic reports at face value.

Most importantly, the court must not just copy the experts' testimonial but rather discuss whether it is dubious that the accused was sane at the time of the crime, as recommended by the Supreme Court. ${ }^{56}$ As part of this, the court must also acknowledge that the judicial assessment of evidence differs from the experts' mandate.

Previously, the jury in the Court of Appeal only answered yes or no to the question of guilt. As of 2018, this is altered. Now the courts have to justify the verdict in the written sentence. I hope this will result in good discussions in the judicial decision and also will lead to more transparency in sentencing. A better understanding of psychiatric and legal dilemmas, both in the legal profession and in the psychiatric community will better the chances of good and correct sentencing in cases where the accused might be 'psychotic'.

I find that legal theory literature has not sufficiently discussed how to handle the difficult cases. There might be uncertainties in the diagnoses, uncertainties in how ill the charged person actually was at the time of the crime, and differences of opinion on how the legal terms are to be understood. However, it is my impression that most cases are not so difficult, and that the psychiatric reports and the legal processing of cases are typically handled very well. In my opinion, it would be better to modify and modernise the legislating, as proposed in NOU 2014:10, rather than to rewrite the law with new legal terms which are only sparsely defined and introduce 'normative ethical, reasonable and just' as new criteria for acquittal.

\section{New Legislation}

After the terror attack in Norway in $2012,{ }^{57}$ a legal board was appointed by the government to revise the insanity legislation. They proposed a bill in $2014,{ }^{58}$ which was processed in the Ministry of Law $^{59}$ and in June 2019 in the Parliament ${ }^{60}$.

The terror attacks and the following trial were objects for public discussion. The first forensic experts found that Mr. Breivik suffered from schizophrenia and he was found 'psychotic' at the time of the crime. Many found this peculiar due to the fact that the attack was complicated and better organised than one would expect from

\footnotetext{
$56 \quad$ Rt-1979-143 on page 147.

57 Rt-2012-1153.

$58 \quad$ NOU 2014: 10.

59 Prop. $154 \mathrm{~L}$ (2016-2017).

60 Innst. 296 L (2018-2019).
} 
an impaired schizophrenic. In prison, the prison psychiatrist did not find him clinically psychotic. The court appointed two new experts, a procedure that sometimes occurs, and they did not find Mr. Breivik filled the legal concept of psychotic. After the weighing of all evidence, the court ultimately found him guilty. Yet the public discussion did not settle. Many people had the impression that it was 'too easy' to be acquitted because of insanity. It was also postulated that the forensic experts had too much influence in these cases.

It was expected that the new revision board would introduce the psychological principle as the prevalent principle, and the board discussed this in detail. ${ }^{61}$ However they settled on continuing the current term 'psychotic' as an absolute reason for acquittal, according to the medical principle. It would be too uncertain if one had to decide if the crime was a result of the illness-how does one decide the true cause in a psychotic brain? They stressed that there was not necessarily accordance between a psychotic illness, diagnosis, and acquittal. They stated that it was the seriousness of the symptoms that are essential, just as the preparatory papers had emphasised in 1990. The board emphasised that the clinical term 'psychotic' was not equivalent to the legal term 'psychotic'. ${ }^{62}$

The board also described how the psychiatric manual for diagnoses, ICD-10, has since 1999 defined several mental abnormalities that were previously considered as insanity as non-psychotic illnesses. Examples of such diagnoses were autism or dementia. They described an example with a young man with an IQ of about 65 and severe autism. He had been considered sane because he was neither psychotic nor severely mentally retarded, but his function was very poor. Therefore, they proposed a new rule (my translation): ${ }^{63}$

'He, whom the court finds psychotic at the time of the crime, or in a state of impaired level of functioning, disturbed cognition and also lacking the ability to understand his relationship to his environment to a similar degree as the psychotic, is not legally responsible.'

This rule emphasises that it is the court's decision whether the offender is to be acquitted. The strength of the symptoms concerning function, cognition and lack of contact with reality is essential for deciding criminal responsibility. This rule does not restrict insanity to a psychiatric diagnosis. This is very sensible in my opinion. It is the Norwegian Parliament that should decide who shall be acquitted and not those who decide the WHO's Manual of Diagnoses, ICD-10 or upcoming ICD-11. The forensic experts must set one or several diagnoses and describe the consequences for the accused person's function and impairment.

NOU 2014: 10.

NOU 1990: 5, p. 51.

${ }_{63}$ Prop. 154 L (2016-2017) on page 46. Original text: 'Den som retten anser for å ha vort psykotisk på handlingstiden eller $i$ en tilstand som med hensyn til sviktende funksjonsnivå, forstyrret tenkning og for øvrig manglende evne til å forstå sitt forhold til omverdenen, må likestilles med å vore psykotisk, er ikke strafferettslig ansvarlig.' 
The proposed bill, as presented in NOU 2014:10, was processed in the Ministry of Law and the result is a law document sent in 2016 to the Parliament. ${ }^{64}$ The law document was very different to the proposal from 2014. The law was passed by Parliament in June 2019 with small alterations, ${ }^{65}$ but is not yet in effect.

The new term for acquittal will be a 'very divergent state of mind'. The substantive aspect of the legal rule is, in my opinion, not clarified at all. ${ }^{66}$ The description of the term 'a very divergent state of mind' is poor, it will include some psychotic cases and some cases with other descriptions and diagnoses.

One reason for changing the law was to prevent the legislation from suggesting that psychotic persons are dangerous and incapable of being held responsible for their actions. The term 'psychotic' was accordingly considered stigmatising.

Another reason to alter the law was to reduce the influence of the expert witnesses. According to the new law, the experts may not discuss whether the accused had a very divergent state of mind, just set diagnoses according to the diagnostic manual and describe his functioning at the time of the crime.

However, the law now also states that it is not sufficient to have a very divergent state of mind at the time of the crime. The court must also 'on an ethical and normative basis' make an independent assessment of whether the defendant's state of mind is 'so divergent that it is not reasonable, just, or expedient to hold him criminally responsible ${ }^{67}$ to acquit the person. However, it is hard to understand what is ethical, normative, or reasonable and just, as this is not clarified. With this new formulation of the law, the medical principle is abandoned without a discussion outside the Ministry. I fear that the content of what is considered 'reasonable and just' leaves the insanity defence to an emotional review. It might now be the consequence that a very psychotic person is sentenced to prison if he or she has committed a number of offences and perhaps also suffers from drug abuse and gives an impression of aggression in court. Conversely, it might now be possible to acquit a sympathetic person suffering unhappily from a mental disease, albeit without so many symptoms as is required today. What seems 'reasonable and just' will most likely differ between the points of view of the victims, the perpetrators, and their families.

The courts often find it difficult to understand the very disturbed reasoning of psychotic persons and that psychotic persons cannot just pull themselves together. I do not believe that the courts understand psychiatric terminology. The experts will have difficulties providing testimony in plain language. I agree with the principle that

64 Prop. 154 L (2016-2017).

65 Innst. 296 L (2018-2019).

66 Prop. 154 L (2016-2017) pp. 19 -121.

67 Idem. p. 68. Original text: '[d]et er retten selv som på etisk og normativt grunnlag [...] selvstendig skal konkludere i tilregnelighetsspørsmålet. [...] det grunnleggende spørsmålet som dommeren må stille seg er hvorvidt lovbryteren på handlingstidspunktet fremsto som så avvikende at det ikke er rimelig, rettferdig eller formålstjenlig å holde ham strafferettslig ansvarlig.' 
the court shall decide, not the experts, but that does not mean that the courts should not be advised. It means that the court must consider the advice, and not automatically copy the experts. I have noticed that neither the preparatory papers nor the bill passed has discussed how the court should handle doubt. I wonder if the supreme court's rule 'the accused must be acquitted if the court-on the bases of the premises in the forensic report or of other reasons-finds it dubious that the accused was sane at the time of the crime', still stands. ${ }^{68}$

I fear this new definition of those who are to be acquitted might result in arbitrary legal practice. One cannot expect lay judges or professional judges to have a good understanding of the very impaired function of the mind if they never have had contact with people with severe mental illnesses. Furthermore, all judges will have different opinion of what is reasonable and just. But of course, if we have a new terrorist like Mr. Breivik, he will be found guilty even if he is very psychotic, because it seems 'reasonable and just' to convict him. 